\title{
The Revival of Civic Nationalism Depended on the Great Depression
}

\author{
Zizhe Wang ${ }^{1, *}$
}

\author{
${ }^{1}$ Beihang University, Beijing, China, 100191 \\ *Corresponding author. Email: 15909205723@163.com
}

\begin{abstract}
The ideal beliefs of United States which comprise the fundamental right of everyone to pursue freedom, equality and to chase happiness have been talked and analyzed proverbially. These values embodied in Declaration of Independence and the Constitution have such an incredible and powerful charm to attract the immigrants all over the world and constitute national identity of American citizens. Scholars have different ways to call these principles, the author prefers Gary Gerstle's term "civic nationalism" to conclude these beliefs because this term has a greater possibility of being applied to more countries, rather than being restricted in United States.

The Immigrant Act during late 1910s and early 20s showed the severe racial tensions. However, during Great depression, racial and religious prejudice declined relatively, civic nationalism had revival in the United States and became a popular tool and method for power, from president to ordinary workers. Conceivably, the time they were consecrated as American Creed was the same time they were relegated to a bargaining chip in political games. Economic depression contributed to civic nationalism unexpectedly and changed the situation of racial nationalism, it created the potential possibility of prosperous of civic nationalism in the 1930s. This paper analyzes the development of civic nationalism during the period of 1929-1937 and derives that the Great Depression is the main reason for the vigorous development of civic nationalism.
\end{abstract}

Keywords: civic nationalism; racial discrimination; the Great Depression; President Franklin Roosevelt

\section{INTRODUCTION}

Around the 1910s was an era of acute racial contradictions. Ku Klux Klan had a strong momentum. Even the racially biased president, Woodrow Wilson, had came up with plans to develop civic nationalism. President Theodore Roosevelt, too, fought for part of the values of the civic nationalism before and during World War I. It is undeniable that Theodore Roosevelt and Woodrow Wilson, while somewhat racially biased, had realized the importance of civic nationalism during the World War I and tried to use this value to achieve their purpose. While both two presidents' political goals and interests were in line with the values of civic nationalism, neither of them accomplished revival of civic nationalism it had achieved during the Great Depression.

They carried forward from two different aspects of civic nationalism. TR emphasized the formation of the American people and hoped to achieve multi-ethnic integration through World War I. Wilson hoped to realize the ambition of a free and democratic world through the Great War. Both two dimension are expressions of civic nationalism. TR tried to alleviate domestic conflicts caused by immigration. If the soldiers merge into a non-discriminatory and undifferentiated nation in the war, the domestic racial sentiment would be eased. Wilson not only hoped to mobilize war by propagating the value of civic nationalism, but also hoped the Great War can achieve eternal peace in Europe and spread of democracy and freedom.

The low degree and limited scope of U.S. military involvement in World War I determined that the war could not carry out Theodore Roosevelt's plan of erasing ethnic differences [1]. Wartime IQ tests which predicated many foreign-born soldiers imbecile who could never become Americans and thus ruined the effort for integrating multiple races into one hardened and superior people [2]. Wilson's mobilization of World War I did succeed in allying American around idealistic values, but the domestic response was not as good as expected. Wilson established the Committee on Public 
Information (CPI) to propagandize the war and reconcile domestic conflicts, but brought opposite effect. CPI's propaganda prompted people to reflect on the unequal status quo in United States and question on how these values of civic nationalism benefited United States. Domestic reflection on civic propaganda made government adopt coercive policies so that keep social stability. After the World War I, anarchists' movement and labors' strike caused the first Red Scare. The government focused on the anti-radical work and the civic nationalism was silent. The Immigration Act was implemented in the 1920s smashed the confidence of southern and eastern European immigrants and East and South Asia immigrants were also excluded. The United States, which claimed to be the beacon of democratic and liberal focused on protecting racial traditions and guarding against threats from other races at that time.

The two presidents failed in their attempts to use civic values to achieve their political purposes. The fundamental reason is that the historical background did not provide a suitable soil for the development of civic nationalism.

\section{FDR'S CONTRIBUTION TO REVIVAL OF CIVIC NATIONALISM}

Unlike Theodore Roosevelt and Wilson, President Franklin Roosevelt did not have racial discrimination and, in many occasion, publicly supported minorities. During the his tenure, civic nationalism resurged. FDR and his New Deal contributed to the revival of civic nationalism, but the resurgence depended on the Great Depression.

The relationship between civic nationalism and FDR's recovery program is reciprocal rather than unidirectional. The primary objective of FDR and New Deal was to recover nation's economy on the brink of collapse. The implementation of the New Deal requires not only the cooperation of citizens, but also the approval of the Congress. As labors' strength became more powerful, their influence on elections also grew stronger. Civic nationalism became the slogan of government in exchange for support. The president was not the only one who using civic values to attract the people; the unions were also using the president's image and civic beliefs to build strength. The president of the United Mine Workers, John L. Lewis, who used rhetorical skills and people's affection for FDR to persuade them to join the union. The ideas he used in appealing people were related to civic nationalism [3].

It is crucial to notice that in the 1930s, the civic nationalism still restricted. FDR seldom showed the same affection and care to some minorities like Mexicans and blacks than European immigrants, and New Deal did not equate the minorities with white citizens. According to the data, the system of exclusion still worked and included two-thirds of all African Americans from the polls in the South [4]. The historian Colin Gordon reassesses the New Deal and concludes that it was highly influenced by conservative interests [5]. In addition to the unequal assistance pushed by the New Deal, FDR's attitude was also right-leaning on the issue of anti-lynching law. Making the lynching as a federal crime, which was the most crucial and urgent request for civic nationalists. In 1933, the National Association for the Advancement of Colored People (NAACP) organized a writers league to fight against lynching. They also launched a nationwide movement to secure a federal anti-lynching law. Contrary to the positive attitude of the first-lady Eleanor Roosevelt, FDR delivered negative attitude about the anti-lynching law. And anti-lynching movement finally failed because Southern senators' refusal [6].

In the election of 1936, FDR turned to left and gave a rousing speech on his renomination. He recognized the strength of labors and problems of monopoly, "Private enterprise, indeed, became too private. It became privileged enterprise, not free enterprise". Obviously, he used civic values against economic royalists, "they denied the right of free assembly and free speech; that they restricted the worship of God; that they put the average man's property and the average man's life in pawn to the mercenaries of dynastic power; that they regimented the people". He declared a war against the economic oligarchs and regards it as his affair, "It is more than that; it is a war for the survival of democracy. We are fighting to save a great and precious form of government for ourselves and for the world" [7]. President Roosevelt and the New Deal objectively promoted civic nationalism. However, president's support is far from enough. If the Great Depression had not built labors' strength, Roosevelt would not choose to support them in 1936. The counter-example is that TR and Wilson failed in using civic values to achieve their purpose because missing the social support and response.

In a conclusion, labor's rise challenged the older political strength. Consequently, the government chose to push the labor benefited policies to satisfy them. New Deal did not take civic nationalism as the ultimate purpose. The Great Depression had a much greater effect on the revival of civic nationalism than FDR and his recovery program.

\section{CAUSAL ANALYSIS OF THE REVIVAL OF CIVIC NATIONALISM IN THE GREAT DEPRESSION}

Great depression was the main cause for the revival of civic nationalism from three aspects.

First of all, the Great Depression gave American a chance to notice that economic inequality was a 
significant weakness of society and it had seriously damaged the country's economic production activities.

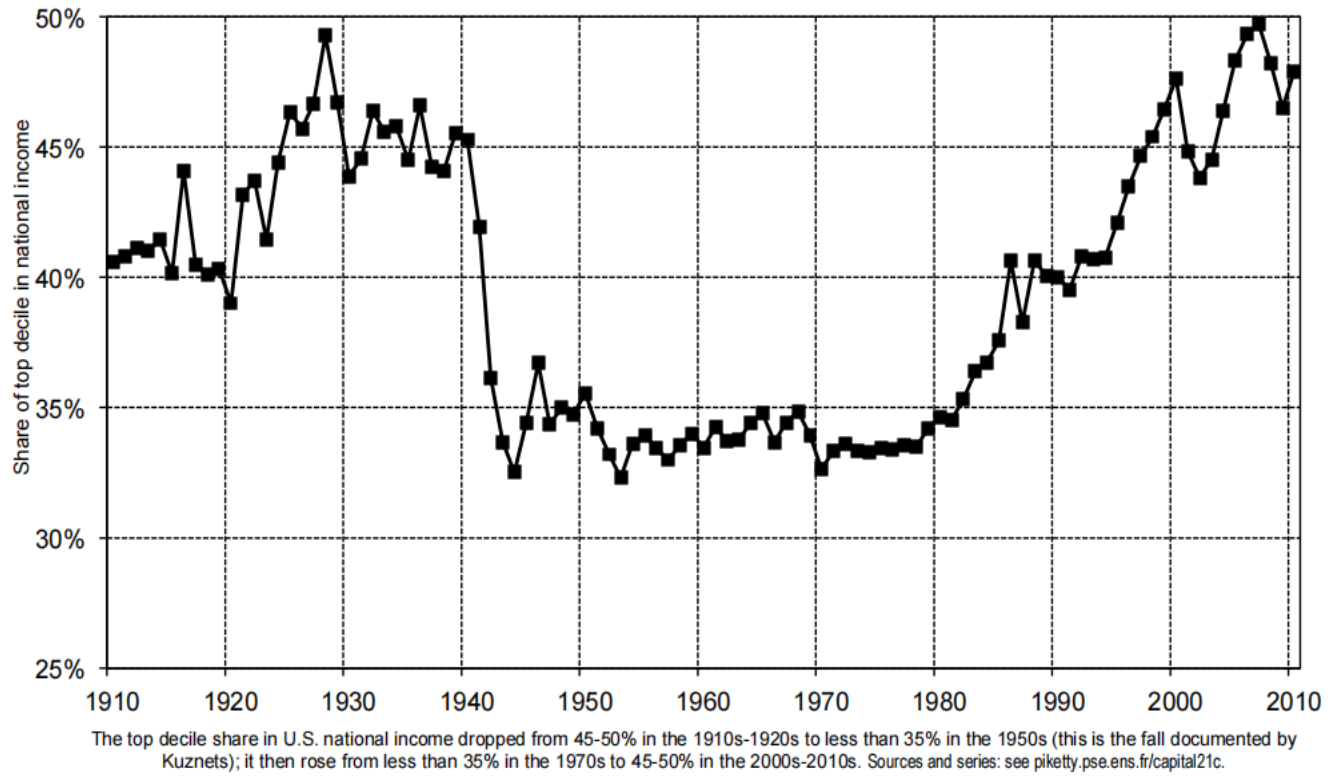

Figure 1 Income inequality in the United States, 1910-2010 [8]

Figure 1 shows the income inequality in the United States. One of the two top decline in national income happened during 1910 s to 1920 s. This national income inequality had led to hatred of economic privilege and the rise of communism. As Gary Gerstle analyzed in The Rise and Fall of the New Deal Order, organized labor were bound together for one creed which ascribe the Depression to "underconsumption" [9]. Congress of Industrial Organizations was one of these radical groups which used civic nationalism to mobilize workers in order to fight for more interests and rights. It took economic oligarchy as their target, set worker's profit as their aim. Strike is the most common method to strive for right. With a belief in increasing workers' purchasing power, unions grew stronger, and they gained strong support for themselves in the White House through the 1936 election. Franklin Roosevelt was re-elected with the support of the labors, but this did not mean that he and his New Deal will strongly support the labor movement. With the FDR's support and advocacy alone far from achieving revival of civic nationalism. TR and Wilson's attempts to use civic nationalism failed missing strong and national wide response, which FDR got, to the values of civic nationalism. The revival of civic nationalism was a joint force. Neither support from president FDR and the New Deal nor the mobilization of labors can be neglected. Nevertheless, the Great Depression had a much greater effect on the revival of civic nationalism than President Roosevelt.

Secondly, the Great Depression destroyed the southern plantation economy and create the conditions for rise of labor. According to historian Wayne Flynt, over 2800 mills and factories had dropped by more than half from 1929 to 1933 [10]. The horrible consequence of Depression led to excess production and worsened the situation of workers. The dull sale of products deprived workers' wage, leading to mass unemployment. Struggling to survive, a large number of black tenant farmers and slaves migrated to industrial cities in the North. The Depression accelerated the black immigration began at 1916 which was a movement of six million African Americans out of the rural southern communities to the urban Northeast, Midwest and West. African Americans made up a large proportion of northern workers. Getting rid of the exploitation from the southern plantation economy and then coming to the big cities in the north far from the ideals of civic nationalism. African Americans confronted many difficulties in the north cities even under the government's alleged civic nationalism policies. Even under FDR, a president without racial discrimination, African Americans did not get equal treatment. Take National Recovery Act as an instance, NRA discriminated against black workers in subsidy policy. Robin D.G. Kelley demonstrates in To Make Our World A New One: "In Atlanta, blacks on relief receive d an average of $\$ 19.29$ per month compared to $\$ 32.66$ for whites. In Jacksonville, Florida, about five thousand whites received $45 \%$ of the relief funds, while the fifteen thousand blacks on relief received the remaining 55\%" [11]. This phenomenon occurred not only in relief funds, but also in terms of minimum wage and support policy. "The NRA removed most blacks from its minimum wage and participatory requirements. Since over sixty percent of African Americans worked in these sectors, the measure had little meaning for most blacks, especially women"[12]. The quoted paragraphs prove that colored workers, despite having some basic civil 
rights, were still discriminated against and faced pressure and protests from white workers. The slogans like "Niggers, back to the cotton fields - city jobs are for white folks" and "No jobs for Niggers Until Every White Man Has a Job" were the best proofs of exclusion of colored workers in northern cities. Not just biased on race, New Deal had also been accused of sexism. New Deal relief agencies were reluctant to aid for unemployed women in afraid of losing men's social status. The Social Security pension system did not cover female occupations intentionally [13].

Thirdly, The Great Depression was so widespread and influential that its aftermath involved all classes of American society. National income dropped by nearly fifty percent, from $\$ 81$ billion in 1929 to $\$ 40$ billion in 1932 [14]. Everyone was overwhelmed by feelings of despair and shock. It was in the context of the Great Depression that conservative and anti-civic forces were willing to compromise, then the civic nationalists were capable of gaining support and achieving goals. The Great Depression also created a context in which forces from all sides were needed to work together to solve the economic crisis, and for those who intended to restore the nation's economy and production, cooperation surpassed contradiction.

The impact of the New Deal on the civic nationalism was limited. The revival of civic nationalism was mainly due to the Great Depression. On the one hand, New Deal's ultimate goal is not to alleviate racial discrimination and contradictions, but to recover national economy. On the other hand, implementation of New Deal needed FDR to compromise with groups who hold racial prejudice. As a consequence, its utility on improving the status quo was limited. On the contrary, the Great Depression made a big difference. Because high unemployment rate and job competition, blacks and whites could work side by side at a cannery in North Carolina whether they like it or not [15]. Comparing to previous decade, there were more unions and groups willing to stand up to the support of the civic values and fight against the racial equality. Racial tensions, though temporarily, eased during the Great Depression.

\section{CONCLUSION}

The revival of civic nationalism was a complicated process in which the government, various labors' unions, and minority organizations had all contributed to its development. This paper claims that the historical context and situation created by the Great Depression were the fundamental conditions for all these organizations to be active. If we ignore the decisive role of the Great Depression, then the rise of civic nationalism would become a manipulation. As a consequence, the revival of civic nationalism depended on the Great Depression.

\section{AUTHORS' CONTRIBUTIONS}

This paper is independently completed by Zizhe Wang.

\section{ACKNOWLEDGMENTS}

Thanks very much to Professor Andrew Preston for the recommending reading materials and providing instruction during the writing process. And the same appreciation to my parents for their encouragement and assistance. This paper could not leave completed without their help and efforts.

\section{REFERENCES}

[1] Gary Gerstle, American Crucible Race and Nation in the twentieth century [M] Princeton, 2001, 98.

[2] Daniel H. Kevles, Testing the Army' s Intelligence: Psychologists and the Military in World War I [J] Journal of American History 55, December 1968, $565-82$.

[3] Melvyn Dubofsky and Warren Van Tine, John L. Lewis: A Biography [M] New York, 1977.

[4] Nancy J. Weiss, Farewell to the Party of Lincoln: Black Politics in the Age of FDR [M] Princeton University Press, 1983

[5] Colin Gordon, New Deals : Business, Labor, and Politics in America .1920-1935 [M] Cambridge University Press, 1994.

[6] Robin D . G . Kelley and Earl Lewis, To make Our World A New [M] Oxford University Press, 2000, 153.

[7] Franklin D. Roosevelt, Acceptance of the Renomination for the Presidency $[\mathrm{N}]$ June 27, 1936.

[8] Thomas Piketty, Capital in the Twenty-first Century [M] Harvard University Press, August, 2013.

[9] Gary Gerstle, The Rise and Fall of the New Deal Order, 1930 - 1980 [M] Princeton, eds., 1989, 34.

[10] Nathan Walker Raby, Pickets, politics, perdition, and perspectives_ The 1934 textile strike in north [J] ProQuest LLC, 2014.

[11] Robin D . G . Kelley and Earl Lewis, To make Our World A New[M], Oxford University Press, 2000, 136.

[12] Robin D . G . Kelley and Earl Lewis, To make Our World A New [M] Oxford University Press, 2000, 137. 
[13] Gary Gerstle, American Crucible Race and Nation in the twentieth century [M] Princeton, 2001, 182.

[14] Robin D . G . Kelley and Earl Lewis, To make Our World A New [M] Oxford University Press, 2000, 131.

[15] Robin D . G . Kelley and Earl Lewis, To make Our World A New [M] Oxford University Press, 2000, 132. 